\title{
Information Simulation of Life Cycle of Building Territory at Master Planning Based on BIM-model
}

\author{
Tetyana Honcharenko ${ }^{1}$, Viktor Mihaylenko ${ }^{2}$, Svitlana Tsiutsiura ${ }^{3}$, Kateryna Kyivska ${ }^{4}$, Olena Balina ${ }^{5}$, \\ Iryna Bezklubenko 5 \\ ${ }^{1} \mathrm{PhD}$ in engineering, Associate Professor, Department of Information Technology, Kyiv National University of \\ Construction and Architecture, Ukraine, iust511@ukr.net \\ ${ }^{2}$ Doctor of Sciences (Engineering), Head of Department of Information technologies of design and applied \\ mathematics, Kyiv National University of Construction and Architecture, Ukraine \\ ${ }^{3}$ Doctor of Sciences (Engineering), Professor, Head of Department of Information Technology, Kyiv National \\ University of Construction and Architecture, Ukraine \\ ${ }^{4}$ Doctor of Sciences (Engineering), Professor, Department of Information technologies of design and applied \\ mathematics, Kyiv National University of Construction and Architecture, Ukraine \\ ${ }^{5} \mathrm{PhD}$ in engineering, Associate Professor, Department of Information technologies of design and applied \\ mathematics, Kyiv National University of Construction and Architecture, Ukraine
}

\begin{abstract}
The article is devoted to information simulation of life cycle of building territory at master planning ased on Building Information Modeling (BIM) technology. The model of building territory is presented as an integrated system, which consumes information from the environment and transmits information about its state to the environment to increase its information potential. In the study process of master planning is carried out in four stages. There are obtaining initial data, assessment and analysis of the resulting a digital terrain model, clarification of the mark of the master planning according to the spatial data of obtaining topographic surveys and geology-based correction. The decision-making algorithm for the master planning of the building territory is developed and presented. The results are BIM model of the macro-planning building territory, working 3D geology and TIN-models of surfaces for each information layer. The study considers eight stages of the life cycle of building territory based on BIM-technology. There are strategic definition, preparation and brief, concept design, developed design, technical design, construction, handover and close out and exploitation. The BIM- model of a building territory at master planning is a set of databases about a construction logical geospace, which are accessed through graphical interfaces various software.
\end{abstract}

Key words: BIM, common data environment, $\mathrm{CDE}$, building territory, territorial planning, spatial data.

\section{INTRODUCTION}

Complex construction projects are becoming an important direction in the formation of sound economic decisions when assessing the possibilities of introducing innovative information technologies [1, 2]. An example of such an innovation is BIM technology, information support for a construction site.

The idea of BIM was born in the 70s of the XX century and has been actively developing since then. BIM technologies belong to the CALS (Continuous Acquisition and Lifecycle Support) family of technologies, which are aimed at continuous information support of supply and product lifecycle. Unlike other representatives of the CALS family, BIM technologies operate with visual infographic presentation of models. An infographic model is an information model of an object or process, which is specified in terms of geometry and graphics (images of abstract space, figures and bodies of real space, etc.). Such a representation makes it possible to impose various interpretations of its functional content on the precise description of the object's shape.

The use of BIM-technology involves working directly with a building model from any type (plans, sections, specifications) with the ability to make automatically synchronized changes. Due to the interdependence of all elements, the model is correctly updated and allows automatically generating updated project documentation.

By creating an accurate digital information model of an object, the integrated information common data environment (CDE) enables all participants in the investment and construction process, according to the regulations, to receive the necessary information about the constructiondesign-modernization object at any time. At the expense of $\mathrm{CDE}, \mathrm{BIM}$ technology allows the investor to control the use and expenditure of funds at all stages of the building project, and the combination with the life cycle of the territory allows to take into account the changes introduced by changes in the characteristics of the territory in the parameters of the building and vice versa.

The territory of the building, depending on its geographical location, climate and other factors, requires additional research to ensure its safe construction and operation.

The analysis of literature sources [7-9] allowed classifying the requirements for the layout of the elements of general 
planning and the main environmental factors that affect their location. The authors of $[10,11]$ propose models by which it is proposed to specify information flows to achieve consistency in all elements of the automated system. In the works of specialists $[12,13]$ the prospects of creating integrated and specialized data warehouses on all aspects of the municipal economy are considered. This topic was further developed in the manuscripts [14-15], in which the infrastructure of three-dimensional spatial data includes the mechanism of accessibility, standardization, accumulation of information exchange, taking into account primarily geodata about the study area by terrain, hydrology, engineering networks and administrative boundaries. Information support of DB is formed by both primary and secondary data. The authors of [16, 17] propose information models of construction object on BIM-Based Design. The accuracy of the primary data determines the resolution parameter when conducting photo fixation, probing, scanning and other types of measurements [18-21].

\section{MAIN RESEARCH}

Building territory should be considered as a complex open system. For a system to operate and interact with the external environment, it must consume information from the environment and transmit information about its state to the environment to increase its information potential. Fig. 1 provides a scheme of the interaction of the building territory with the external environment.

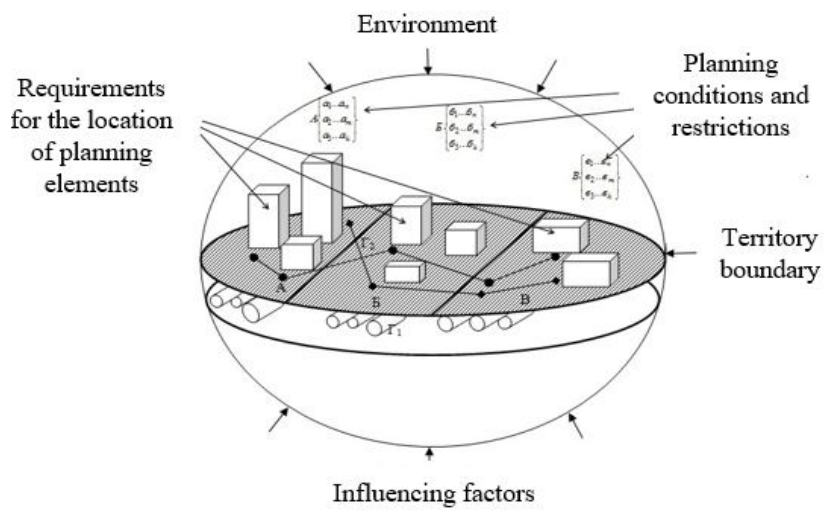

Figure 1: Scheme of interaction of the building territory with the external environment

Thus, the area intended for development is considered as a logical geospace and is a source of information about the location of planning elements. The assessment of the suitability or unsuitability of the site for development can be based on one of the factors provided in the studies, and a combination of them. Factors influencing the structure of planning restrictions on land use:

$$
f\left(x_{i}\right)=f\left(x_{1}, x_{2}, x \ldots, x_{n}\right) \rightarrow\left\{\begin{array}{l}
a_{1}, \ldots, a_{n} \\
b_{1}, \ldots, b_{n} \\
c_{1} \mid, \ldots, c_{n}
\end{array}\right\}
$$

where $f\left(x_{i}\right)$ is a function of the suitability of the building territory; $x_{1}, x_{2}, \ldots, x_{n}$ are factors of influence; $a_{1}, \ldots . a_{n}$, $b_{1}, \ldots b_{n}, c_{l}, \ldots . c_{n}$ are planning constraints.

The study of information data to solve the problems of land planning allows us to propose a functional model of planning the territory for construction, which is presented in fig. 2 .

Influence factors

Planning conditions and restrictions

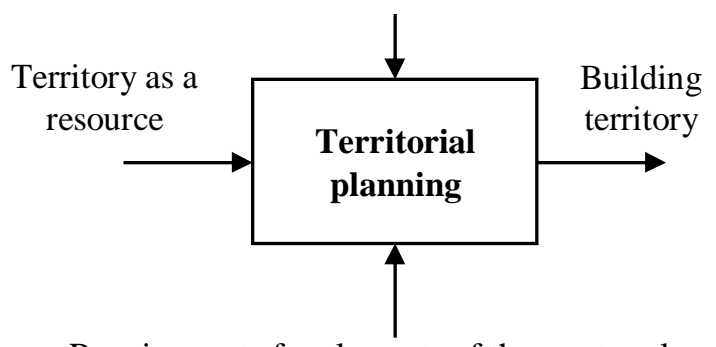

Requirements for elements of the master plan Functional purpose

Figure 2: Functional model of the territory planning for construction

To generate spatial information about a building area, BIM technology allows, along with traditional methods of geodetic surveys, to use high-performance measuring systems for ground and air mobile laser scanning, which are currently one of the most effective methods for collecting and recording spatial data. The result of laser scanning is point clouds, which, along with other sources of information about the construction object (drawings, pictures, photographs, videos, available databases, etc.) are the initial data for creating an information model of the building area.

In fig. 3 shows a diagram of the process of collecting and registering spatial data to create a BIM model.

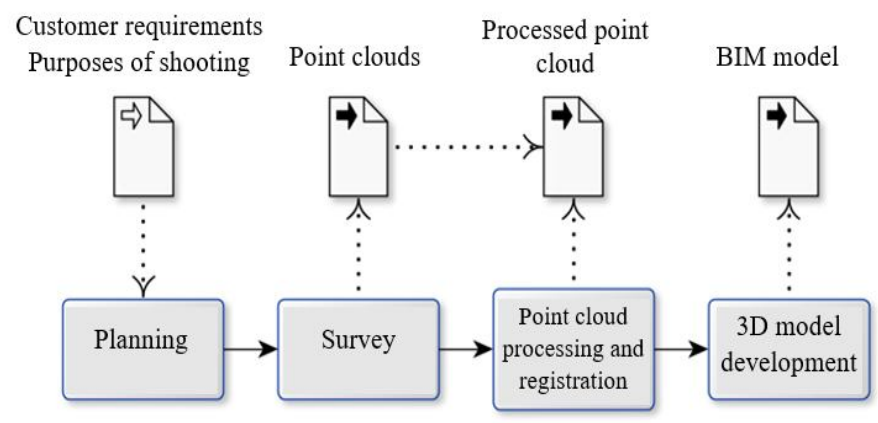

Figure 3: The process of collecting and registering spatial data for creating a BIM model

Part of the development of a conceptual model of a building territory is master planning, which is performed according to the following algorithm, shown in Fig. 4.

Master planning is carried out in four stages:

Stage I. Obtaining initial data.

Initial data for creating a digital terrain model (DTM) serve as the basis for making decisions on the Master-planning of the Building territory. They can be obtained in two ways: 
Tetyana Honcharenko et al., International Journal of Emerging Trends in Engineering Research, 8(10), October 2020, 7337 - 7343

- From open sources.

- Based on the results of existing engineering and topographic surveys and raster images of the relief.

Path 1. Open data sources.

Today there are many open sources of information on the Internet. They can be both paid and free. The files with information about the terrain mainly have the extension STRM (Shuttle Radar Topography Mission) - radar topographic survey of most of the globe. Some sources of downloadable information can be found at the following addresses:

- Autodesk Infraworks has a Model Builder tool where select only the area of interest.

- Once this information is received, it is processed in the Infraworks environment. The result of its processing is a model with a relief surface, which can be linked to AutoCAD Civil 3D.

Path 2. Retrieving data from existing information and raster.

Existing DWG data must be processed in AutoCAD Civil 3D to create a TIN surface. Here it is necessary to analyse what objects the terrain survey consists of and what attributes these objects have. Data presented in the form of raster images must first be processed in AutoCAD Raster Design, resulting in objects with the necessary attributes, and then, with the AutoCAD Civil 3D tools, to obtain a TIN surface.

Thus, the result of stage $I$ is to obtain a TIN surface for preliminary modelling of Building territory.

Stage II. Assessment and analysis of the resulting DTM. After obtaining the TIN surface, it is necessary to analyse it for elevation differences, the nature of the relief and the type of terrain. To determine the preliminary mark of Master-planning, it is mainly necessary to be guided by the balance of earth masses. As a rule, at this stage there is no data from engineering-geodetic and engineering-geological surveys. After receiving data on complex engineering surveys, the elevation of the master planning can be adjusted.

Phase II should result in a clear understanding of the complexity of the terrain, preliminary marking of master planning, preliminary volumes of earthworks, solutions for strengthening slopes in vertical planning, as well as preliminary solutions for the engineering arrangement of the Building territory.

Stage III. Clarification of the mark of the master planning according to the results of obtaining topographic surveys. After receiving the engineering survey data, it is necessary to correct the existing TIN surface obtained in stage I. The data is processed in Civil 3D and loaded into the existing surface. After that, it is necessary to adjust the mark of the master planning, based on the conditions that were described above. Stage III should result in a corrected TIN surface, as well as the amount of earthwork.

\section{Stage IV. Geology based correction.}

Geological data can have a significant impact on the choice of the building territory master plan elevation. Buildings and structures cannot be placed on "weak" soils without appropriate measures concerning the foundation and the soil itself. Therefore, for further design stages (Design Documentation and Working Documentation), it is necessary to obtain geological information on the types and characteristics of soils. In this regard, it is necessary to create a working geological 3D model of the Building territory. For this, it is recommended to use the Geotechnical Module software product. With its help, layer-by-layer TIN surfaces are obtained for each soil. After creating a geological 3D model, it is necessary to adjust the master level elevation again, taking into account the working geological model.

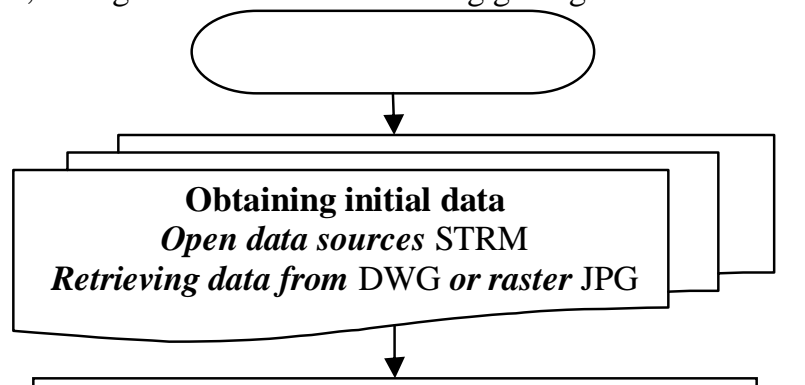

Stage I. Creation of digital terrain model DTM Obtaining surface TIN-model of the relief

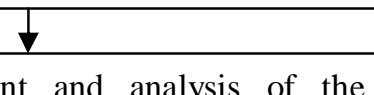

Stage II. Assessment and analysis of the resulting DTM

Preliminary master planning building territory

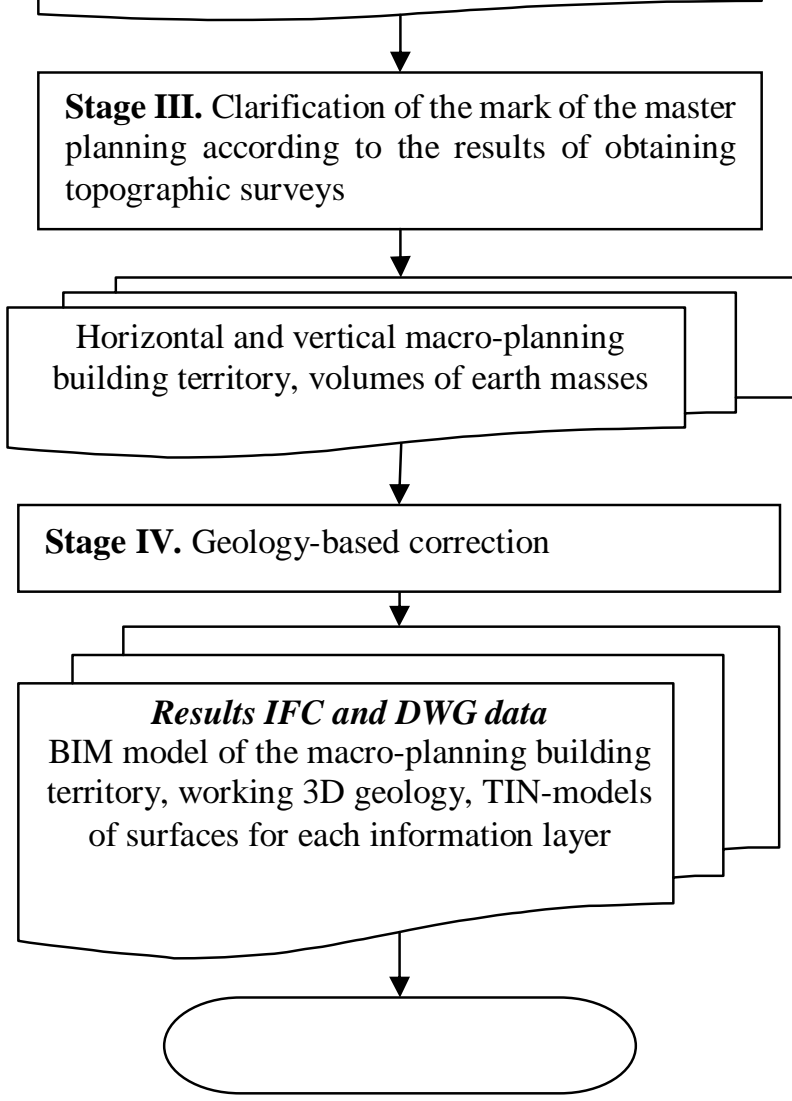

Figure 4: Decision-making algorithm for the master planning of the building territory 
The result of stage IV should be a working 3D geology, layered surfaces for each of the soils, taking into account the refinement of pinch outs and lenses, as well as an adjusted master levelling mark.

Comprehensive monitoring during the operation of a building and its location is a technology for detecting systemic changes in the functioning of each of these objects. At the same time, as the territory of the building location depends on the place of its geographic referencing, hydrological characteristics of the soil, climate and other factors, so the building design and its implementation depend on changes in the characteristics of the territory.

Comprehensive monitoring is represented by a systemic combination of various monitors using BIM technologies, which allow a systematic approach to determining the state of the external environment of a building and its location and make a reliable conclusion about the forecast of their functioning as part of a complex reconstruction object.

Throughout the entire life cycle of a construction object, a huge amount of information is generated that must be managed and stored in some form. To solve these problems, modern technologies and software are used.

The most promising technology that allows you to work with information about a building object is information modeling. This technology makes it possible to work with data throughout the entire life cycle of a building and affects many aspects of construction, such as building business processes, architectural design, strength calculations, facility operation, etc.

When developing this complex, the life cycle of the building's supporting structures is described harmoniously using information modeling technology, from design to disposal.

Is defined as the period during which engineering surveys, design, construction (including conservation), operation (including current repairs), reconstruction, overhaul, demolition of a building or structure are carried out.

This definition does not contain the early developments of Ukrainian scientists, and also does not correspond to the description of the life cycle adopted abroad.

Prior to the active development of information modeling, the definition of the life cycle of a building was formulated by $\mathrm{M}$. Dyomin and A. Dmytrenko [20] as the time from the moment of substantiating the need to erect a building until the onset of economic inexpediency of its further operation. The authors identified the following periods (stages) of the building's life cycle:

- feasibility study for the construction of the facility;

- its construction and design;

- development of technology, organization and technological regulations for the production of work;

- pre-operational development;

- operation of buildings and operating time, allowing to ensure the payback of funds invested in their creation and development;

- maintenance of structural elements and engineering systems of the building in a normal technical condition through scheduled preventive and major repairs;

- physical and moral deterioration, requiring modernization, reconstruction or demolition of the building. The last state is both the period of the end of the life cycle of one object and the beginning of a new one;

- reconstruction, restoring the physical, mechanical and operational characteristics of the building and including a feasibility study and development of technical documentation. With such a division of the life cycle periods, the building is considered as a building system with structural elements of different durability.

The stable state of the system is characterized by its equilibrium over a long period of time. The information modeling technology itself does not make it possible to predict the service life of materials and individual structures, but it helps to increase the overall safe operation of a building by making competent design decisions due to the availability of access to information about the object at any time.

Information about such impacts should be stored in the information model, and a rational decision based on this information should be made by a specialist.

The use of the technology under consideration can reduce the loss of information, which was described in detail by the founders of information modeling (C. Eastman, P. Teicholz, R. Sacks, K. Liston) [17, 22].

Since the information model is a database, it is logical to enter events that occur with a building during the life cycle in the form of blocks (sets) of information. The modified carrier system reliability graph is shown in $[17,22]$. The blocks of the stage and blocks-actions shown on the graph should be created according to the given rules and include certain information.

The life cycle of a construction object can be written in the form of diagrams to automate decision-making at various periods of operation. Information delivery guidelines such as ISO 29481-1: 2010, ISO 29481-2: 2012 state that a complete information exchange framework that encompasses all information for all persons involved in a project throughout life the cycle of the building will be enormous and cannot be applied in practice. To do this, the general scheme is divided into components described by guides for the delivery of information (implementation of information tasks).

The correct creation of the Information Delivery Manual is only possible with a classification system like Omniclass or Uniclass. Own classifiers in accordance with Omniclass have: building objects (by function and form), spaces (by function and form), elements (constructive, interior and others), results of work, products for construction, phases (analogs of life cycle stages), services, disciplines, organizer roles, tools, information, materials and properties.

The scientific novelty of the study is to develop a functional model of the territory planning for construction and BIM-model of life cycle of building territory at master planning.

The practical significance of information simulation of life cycle of building territory based on BIM-model is to create a single integrated information space for project decisions at master planning. 


\section{RESULTS AND DISCUSSION}

The life cycle of building territory using information modeling is described in the most detail in $[2,13,14,16,22]$. In the PAS series of standards, there is a division of the entire life cycle into the following stages:

- from the moment of strategic planning and preparation of the design assignment to the transfer of the facility into operation;

- stage of operation and dismantling of the building. Basic works on information modelling include 8 stages:
0. Strategic Definition;
1. Preparation and Brief;
2. Concept Design;
3. Developed Design;

4. Technical Design;

5. Construction;

6. Handover and Close Out;

7. Exploitation.

All kinds of events shown by the letter in table 1 refer to the operational stage. There can be any number of such events, depending on the object management strategy. Their example is reconstruction, repair, transfer of the building to another owner, etc.

The main works on information modeling are brought in accordance with the current stages and are summarized in the table. In addition to these works, data is transferred to the customer throughout the entire life cycle of building territory.

Table 1: Basic works on information modelling

\begin{tabular}{|c|c|c|}
\hline $\begin{array}{c}\text { Stage } \\
\text { number }\end{array}$ & Project stage & Information modelling works \\
\hline \multirow[b]{2}{*}{0} & \multirow{2}{*}{$\begin{array}{l}\text { Strategic } \\
\text { definition }\end{array}$} & Advising a customer on the purpose of using information modelling technology \\
\hline & & $\begin{array}{l}\text { Advising the customer on attracting a specialist who manages the information model at various } \\
\text { stages of its life cycle }\end{array}$ \\
\hline \multirow{4}{*}{1} & \multirow{4}{*}{$\begin{array}{l}\text { Preparation and } \\
\text { Brief }\end{array}$} & Determination of long-term rights and obligations for the information model \\
\hline & & $\begin{array}{l}\text { Development and approval of requirements for information models and the scope of their } \\
\text { application }\end{array}$ \\
\hline & & Establishing the scope of the assessment of the building after the start of its operation \\
\hline & & Determining the amount of information that needs to be obtained through research \\
\hline \multirow{5}{*}{2} & \multirow{5}{*}{$\begin{array}{l}\text { Conceptual } \\
\text { project }\end{array}$} & Pre-launch meeting on working with information modelling technology \\
\hline & & Design variants \\
\hline & & Use of information to determine environmental parameters and area analysis \\
\hline & & Ensuring access of the project team to the data on the object \\
\hline & & Coordination of work performed by a specialized subcontractor \\
\hline \multirow{4}{*}{3} & \multirow{4}{*}{ Developed Design } & Exchange of information between different sections of documentation. Search for collisions \\
\hline & & Development of project components \\
\hline & & Use of information to clarify environmental parameters and areas \\
\hline & & Data exchange for design coordination, technical analysis and specification \\
\hline \multirow{6}{*}{4} & \multirow{6}{*}{ Technical Design } & Works similar to stage 3 \\
\hline & & Inclusion of specifications in the model \\
\hline & & Formation and evaluation of 4D and 5D models \\
\hline & & Data exchange and detailed analysis of the work of the general designer and subcontractors \\
\hline & & Development of detailed models for production \\
\hline & & Final verification and approval of the model \\
\hline \multirow{4}{*}{5} & \multirow{4}{*}{ Construction } & Export of data for construction control \\
\hline & & Providing the construction organization with access to the information model \\
\hline & & Integration of data from the construction site into the information model \\
\hline & & Carrying out the analysis of construction works according to the schedule (4D) \\
\hline \multirow{2}{*}{6} & \multirow{2}{*}{$\begin{array}{l}\text { Handover and } \\
\text { Close Out }\end{array}$} & Coordination of terms and volumes of works for commissioning of object \\
\hline & & Coordination and publication of information model data at the construction stage \\
\hline \multirow{2}{*}{7} & \multirow{2}{*}{ Exploitation } & Making changes to the information model during the operation of the building \\
\hline & & Study of information about the objects of the building included in the information model \\
\hline
\end{tabular}


The approach to the implementation of the project with a breakdown at the stage involves the predetermination of various tasks of information modeling (BIM Uses), the interaction between the persons involved in the construction process at all stages of the life cycle of the building. Decision-making on the choice of tasks is carried out by managing the life cycle to achieve the objectives of the project and maintaining a balance between cost, risk, quality and other parameters.

Analysis of the works of American scientists [16] showed that the number of information modeling problems in the life cycle of an object exceeds 1000. Thus the tasks involving only the experts developing the following sections are involved: the general plan, external networks, architecture, designs, and engineering networks. The classification of information modelling problems is presented in the table 2 . This scheme takes place at certain stages of the life cycle of the object, the rules of formation of tasks and types of work with information. At the moment, these issues are not addressed in the regulatory documentation of our country.

Table 2: General classification of information modelling tasks

\begin{tabular}{|c|c|c|c|c|c|c|c|c|c|c|c|c|c|}
\hline \multirow{4}{*}{ 1. Collection of information } & 1. Data entry & \multirow{18}{*}{ 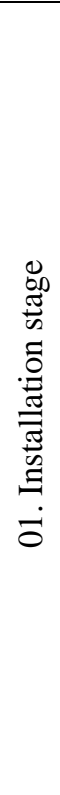 } & \multirow{18}{*}{ 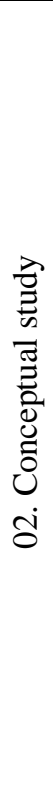 } & \multirow{18}{*}{ 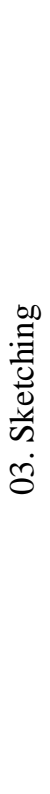 } & \multirow{18}{*}{ 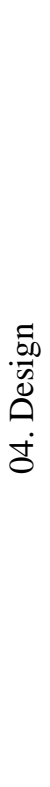 } & \multirow{18}{*}{ 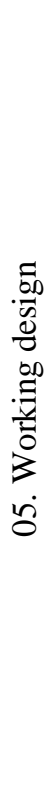 } & \multirow{18}{*}{ 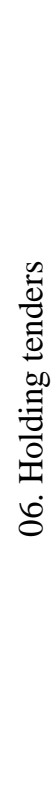 } & \multirow{18}{*}{ 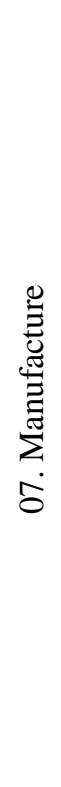 } & \multirow{18}{*}{ 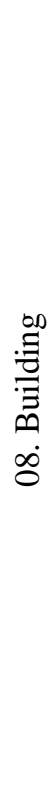 } & \multirow{18}{*}{$\begin{array}{l}.0 \\
.0 \\
\cdot 0 \\
0 \\
0 \\
0 \\
0 \\
0 \\
0 \\
0\end{array}$} & \multirow{18}{*}{ 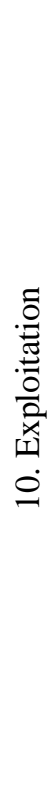 } & \multirow{18}{*}{ 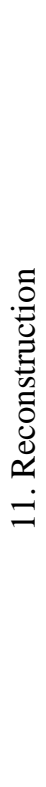 } & \multirow{18}{*}{ 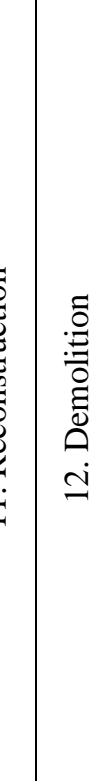 } \\
\hline & 2. Counting data & & & & & & & & & & & & \\
\hline & 3. Data control & & & & & & & & & & & & \\
\hline & 4. Data identification & & & & & & & & & & & & \\
\hline \multirow{3}{*}{ 2. Formation of information } & 1. Purpose of data & & & & & & & & & & & & \\
\hline & 2. Data placement & & & & & & & & & & & & \\
\hline & $\begin{array}{l}\text { 3. Determination of } \\
\text { dimensions }\end{array}$ & & & & & & & & & & & & \\
\hline \multirow{3}{*}{ 3. Analysis of information } & 1. Data coordination & & & & & & & & & & & & \\
\hline & 2. Simulation of processes & & & & & & & & & & & & \\
\hline & 3. Data reconciliation & & & & & & & & & & & & \\
\hline \multirow{4}{*}{ 4.Information exchange } & 1. Data visualization & & & & & & & & & & & & \\
\hline & 2. Data transformation & & & & & & & & & & & & \\
\hline & 3. Data schematization & & & & & & & & & & & & \\
\hline & 4. Documentation & & & & & & & & & & & & \\
\hline \multirow{4}{*}{$\begin{array}{l}\text { 5. Embodiment of } \\
\text { information }\end{array}$} & 1. Production of parts & & & & & & & & & & & & \\
\hline & 2. Assembly of parts & & & & & & & & & & & & \\
\hline & 3. Management of equipment & & & & & & & & & & & & \\
\hline & 4. Facility management & & & & & & & & & & & & \\
\hline & & \multicolumn{5}{|c|}{ Master plan } & \multicolumn{7}{|c|}{ Plan of engineering networks } \\
\hline
\end{tabular}

\section{CONCLUSION}

1. The information model of a building territory is a database about a construction object, which is accessed through graphical interfaces various software.

2. Information modeling does not solve the problems of predicting the durability of buildings and structures, but allows obtaining a complete set of data about a building at any stage of its life cycle. Having this data, specialists have to make rational decisions about the further operation of the building.

3. Information models should reflect the actual state of the building at all stages of its life cycle. Building territory should be considered as a complex open system. It is advisable to develop and implement the system with principles of information modeling of the life cycle, including at the level of national legislation.

4. It seems important for the further formation of methodological documents in the field of construction information management, the creation of systems for its classification and general terminological foundations.

\section{REFERENCES}

1. T. Honcharenko, Y. Chupryna, I. Ivakhnenko, M. Zinchenco, T. Tsyfra. Reengineering of the Construction Companies Based on BIM-technology, International Journal of Emerging Trends in Engineering Research, 8(8), August 2020, pp. 4166-4172 https://doi.org/10.30534/ijeter/2020/22882020

2. V. Mihaylenko, T. Honcharenko, K. Chupryna, Yu. Andrashko and S. Budnik. Modeling of Spatial Data on the Construction Site Based on Multidimensional Information Objects. International Journal of Engineering and Advanced Technology. Volume-8 Issue-6, pp.3934-3940, August 2019. URL: https://www.ijeat.org/wp-content/uploads/papers/v8i6/F 9057088619.pdf

3. O. Terentyev, S. Tsiutsiura, T. Honcharenko and T. Lyashchenko. Multidimensional Space Structure for Adaptable Data Model, International Journal of Recent Technology and Engineering (IJRTE), Volume-8 Issue-3, pp. 7753-7758, September 2019. URL: https://www.ijrte.org/wp-content/uploads/papers/v8i3/C 6318098319.pdf 
4. M. Ahmad, T. Sinelnikova, S. Mustafa, V. Lyashenko. Features of the Construction and Control of the Navigation System of a Mobile Robot. International Journal on Emerging Trends in Engineering Research, 8(4), pp. 1445-1449, April 2020. https://doi.org/10.30534/ijeter/2020/82842020

5. S. A. De Santana. Modeling urban landscape: new paradigms and challenges in territorial representation, Disegnare con., 2013, no. 6(11), pp. 161-174, DOI 10.6092/issn.1828-5961/3379

6. A. Kuchansky, Y. Andrashko, A. Biloshchytskyi, O. Danchenko, O. Ilarionov, I. Vatskel and T. Honcharenko. The method for evaluation of educational environment subjects' performance based on the calculation of volumes of M-simplexes in Eastern-European Journal of Enterprise Technologies, 2 (4-92), pp. 15-25, http://journals.uran.ua/eejet/article/download/126287/12 5235

7. D. Ryzhakov, O. Dikiy, M. Druzhynin, H. Petrenko and T. Savchuk. Innovative tools for management the lifecycle of strategic objectives of the enterprise-stakeholder in construction, International Journal on Emerging Trends in Engineering Research, 8(8), 2020, pp. 4526-4532, https://doi.org/10.30534/ijeter/2020/78882020

8. I. Arutiunian, M. Poltavets, O. Bondar, V. Anin and F. Pavlov. Structural Information Management of Production Systems in Construction, International Journal of Advanced Trends in Computer Science and Engineering, 9(4), July-August 2020, pp. 4794 - 4797, https://doi.org/10.30534/ijatcse/2020/87942020

9. A.V. Burkov, R.V. Pshenichnov, T.V. Yalyalieva. Construction of models for conversion of mortgage applications by the method of multiple regression and Neural Networks, International Journal of Advanced Trends in Computer Science and Engineering, 9(4), July -August 2020, pp. 4546-4550, https://doi.org/10.30534/ijatcse/2020/52942020

10. K.I. Kyivska, S.V.Tsiutsiura, M.I.Tsiutsiura, O.V. Kryvoruchko, A.V.Yerukaiev and V.V.Hots. A study of the concept of parametric modeling of construction objects, International Journal of Advanced Research in Engineering and Technology, Volume 10, Issue 2, 2019, pp 636-646.

11. Y. Riabchun, T. Honcharenko, V. Honta, K. Chupryna, O.Fedusenko. Methods and means of evaluation and development for prospective students' spatial awareness, International Journal of Innovative Technology and Exploring Engineering, Volume 8, Issue 11, September 2019, pp. 4050-4058, https://www.ijitee.org/wp-content/uploads/papers/v8i11/ K15320981119.pdf

12. O. Shushura, L. Asieieva, I. Husyeva, M. Stepanov, O.Datsiuk. Construction of models for conversion of mortgage applications by the method of multiple regression and Neural Networks, International Journal of Advanced Trends in Computer Science and Engineering, 9(3), May-June 2020, pp. 2702-2707, https://doi.org/10.30534/ijatcse/2020/33932020
13. A. G. Myasnikov. Information and logical modeling in construction, International Journal of Advanced Trends in Computer Science and Engineering, 9(1), January -February 2020, pp. 304-307, https://doi.org/10.30534/ijatcse/2020/46912020

14. N. V. Danilina. Application of BIM-Technologies at the Stage of Urban Planning Design, Promyshlennoe $i$ grazhdanskoe stroitel'stvo [Industrial and Civil Engineering], 2018, no. 9, pp. 48-52. (In Russian)

15. A. Kuchansky, A. Biloshchytskyi, Yu.Andrashko, S. Biloshchytska, T. Honcharenko, V.Nikolenko. Fractal Time Series Analysis in Non-Stationary Environment, 2019 IEEE International Scientific-Practical Conference: Problems of Infocommunications Science and Technology, PIC S and T 2019 - Proceedings, 2019, pp. 236-240.

16. S.A.Biancardo, N. Viscione, A. Cerbone and E. Dessì. BIM-Based Design for Road Infrastructure: A Critical Focus on Modeling Guardrails and Retaining Walls, Infrastructures, 2020, 5, 59, https://doi.org/10.3390/infrastructures5070059.

17. R.Sacks, C.Eastman, G. Lee and P. Teicholz. BIM Handbook: A Guide to Building Information Modeling for Owners, Designers, Engineers, Contractors, and Facility Managers, 3rd ed.; John Wiley \& Sons: Hoboken, NJ, USA, 2018, p. 688.

18. D. Chernyshev, D.Ryzhakov, O. Dikiy, O. Khomenko and S. Petrukha. Innovative Technology for Management Tools of Commercial Real Estate in Construction, International Journal on Emerging Trends in Engineering Research, 8(9), September 2020, pp. 4967-4973, https://doi.org/10.30534/ijeter/2020/13892020

19. À. V. Belyaev and S. S. Antipov. Life Cycle of Construction Objects at Information Simulation of Buildings and Structures, Promyshlennoe $i$ grazhdanskoe stroitel'stvo [Industrial and Civil Engineering],2019, no. 1, pp. 65-72. (In Russian)

20. M. Dyomin A. Dmytrenko, D. Chernyshev and O. Ivashko. Big Cities Industrial Territories Revitalization Problems and Ways of Their Solution, Lecture Notes in Civil Engineering, 73, 2020, pp. 365-373.

21. P. M. Kulikov, N. Y. Zhuravska and A. M. Savchenko. Modern Possibilities of Management of Technogenic-Natural Systems of Heat-Energy Objects of Industrial and Construction Industry, Lecture Notes in Civil Engineering, 73, 2020, pp 115-121

22. C. Eastman. et al. BIM Handbook. A guide to building information modeling for owners, managers, designers, engineers and contractors, TH437.B53, 2011, 650 p.

23. T. Honcharenko, Yu. Andrashko, O. Fedusenko, I. Domanetska and N. Olhova. The method of generalizing spatial information into a single multidimensional data model, International Journal of Recent Technology and Engineering, Vol. 8, Issue 4, 2019, pp. 8426-8432. 